\title{
THE RESISTANCE OF AFRICAN TRADITIONAL RELIGION (ATR) TO CHRISTIANITY: A HISTORICAL PERSPECTIVE
}

\author{
Francis Ohiemi Edimeh \\ Department of History, Kogi State College of Education, Ankpa, Kogi State, Nigeria
}

\begin{abstract}
The vigor with which the African Traditional Religion (ATR) has continued to resist the onslaught of Christianity is a cause of academic preoccupation. Philosophers, sociologists, theologians, religious leaders, etc have pondered on how Christianity which is highly organized, armed with a Scripture, an army of missionaries and backed by an acclaimed superior culture; unexpectedly could not and still cannot decimate the adjudged inferior religion of the Africans. Historians are not left out in this inquiry. Thus, this paper examined the historical perspective of the issue. With information garnered from relevant literature, this paper investigated the deep spiritual and cultural attachment of Africans to their indigenous religion even when they professed Christianity; and how it was this same attachment and resilience that made the Africans to export their religion to Europe, America and the Caribbean.
\end{abstract}

Keywords: African Traditional Religion, Christianity, Syncretism.

\section{INTRODUCTION}

African Traditional Religion or African Indigenous Religion(s) (as some people prefer to call it), is the inborn and aboriginal religion of the Africans (Adamo, 2011). Two major immigrant religions, Islam and Christianity were later introduced to Africa and have had great impact on the African peoples. These foreign religions were well equipped for the battle for the soul of Africa. Unlike the ATR, Christianity had scriptures and a well organized structure that supported active evangelization. This was the basis of what Adamo (2011) described as Christianity's unbridled feeling of superiority. With this scenario, it was expected that supplanting the ATR would be mincemeat. However, that has not been possible.

During the Trans Atlantic Slave Trade (1500-1900), Africans were exported as slaves to the Caribbean and the Americas. There, the slave masters tried to suppress the practice of African Traditional Religion by the slaves. The result was a fusion of African religious forms and Christianity. Even today, syncretism between the two religions still exists. The ATR has refused 
International Journal of Arts and Humanities

ISSN: 2581-3102

Volume: 04, Issue: 02 "February 2020"

to be conquered by Christianity. Scholars and religious leaders have attested to the strength and resilience of ATR. Cardinal Jean L. Tauran, the President of the Pontifical Council for InterReligious Dialogue is someone considered as an authority in world religious affairs. According to Sourou (2014), Tauran affirms that the African Traditional religion still exercises a strong influence over Africans who he described as naturally religious. On his own part, Adamo (2011) attested to the fact that the ATR has continued to manifest vitality.

This paper intends to examine the source of the strength of ATR. In doing so, the history of Christianity in Africa shall be surveyed followed by an examination of its core beliefs as well as that of ATR. Theories of religion shall be adopted as a framework. And after examining the appeal of ATR vis-à-vis Christianity, the export of the former to the Diaspora shall be discussed. Finally, a conclusion shall be drawn.

\section{CHRISTIANITY IN AFRICA}

Christianity has been described as a religion that is based on the life, teachings and example of Jesus Christ and the belief that He was the son of God (Hornby 2010; Encarta Dictionaries). With roots in Judaism, the religion started in Judea where Jesus preached repentance, taught about the Kingdom of God and healed the afflicted. After Him, his disciples continued the work under the leadership of Saint Peter. Saint Paul was the anchor of the spread of Christianity outside the Jewish territory. Thus the religion spread to Asia, Europe, Africa and now the entire world.

During the $1^{\text {st }}$ Century AD, Christianity spread across North Africa more by conversion than migration. There arose in that area a robust Christian civilization. From Egypt, the Coptic Church waxed strong and extended its influence in the Oriental world. Great doctors of the Church were products of the vibrant Christian activities in Africa. Unfortunately, due to internal and external factors, Christianity declined in Africa. In 639 AD, Islam began its march across North Africa. Many people in North West Africa saw Islam as a vibrant spiritual and material alternative to a decaying Christian world. Finally, by 788, the forces of Islam conquered the centers of Eastern Christianity. Only scattered Catholic communities survived into the $15^{\text {th }}$ century (Newman 2008).

In the mid $19^{\text {th }}$ century, there were Christian revival movements in Europe. Consequently, missionaries reintroduced Christianity to Africa. While the Christian missionaries contributed to the establishment of colonial rule on one hand, on the other, the latter boosted the process of winning converts. Education and health services also attracted Africans to Christianity. Today, new Churches that combine Christian doctrines and rituals with indigenous African religious practices are becoming increasingly common in African countries (Newman et al, 2008). 
International Journal of Arts and Humanities

ISSN: 2581-3102

Volume: 04, Issue: 02 "February 2020"

\section{THE CORE BELIEFS OF CHRISTIANITY}

Christianity has been described as a way of life, a system of belief, a liturgical observance and a tradition (Encarta ${ }^{\mathrm{R}}$ 2009). At the center of the faith is the person of Jesus Christ and the belief that $\mathrm{He}$ was the revealer not only of human life in its perfection, but of divine reality itself. Jesus is the son of God. His crucifixion and death reconciled humanity to God and made the Cross the main focus of Christian faith and devotion (Encarta ${ }^{R}$ 2009). His resurrection and the descent of the Holy Spirit invigorated Christianity. Central to Christianity is also the idea of the saving love of God the father. God is almighty in dominion over heaven and earth, righteous in judgment over good and evil and is beyond space, time and change. Yet, He is love.

Equally important in Christian doctrine are the concepts of Trinity, Baptism and the Eucharist. The Church is the Christian community. It is believed that the promise of Jesus to be with Christians always to the close of the age found its fulfillment in His mystical body on earth -the holy Catholic Church.

\section{CORE BELIEFS OF AFRICAN TRADITIONAL RELIGION}

The single term African Traditional Religion does not connote a uniform religious practice. In fact, there are a variety of forms in different parts of the continent. Thus, some scholars prefer to call it African Indigenous Religions (AIR) (Adamo 2011). However, general characteristics are identifiable. It is also worthy of note that in ATR, there is neither a claim of revelation nor theology and doctrine that are documented in books. Rather, the religious system developed experientially (Nwokoro 2014) and manifests practical theology in pragmatic existential context (Acquah 2011). Africans had developed a variety of religious and social practices, rituals and ceremonies in order to establish links and relationships with cosmic spiritual and mystical powers (Turaki, African Traditional).

In ATR, there is the belief in a Supreme Being who creates, sustains, provides, delivers, rules and dispenses justice (Nwokoro 2014). He is given different names and attributes and so many myths are built around Him. He is worshipped through consultation or communion with lesser deities and ancestral spirits. These deities and spirits which are honored through sacrifices and libation have specific areas of influence in human lives. Boaheng (2012) notes that the lesser gods were the focal point of ritual activities and many shrines were dedicated to them. He continued to explain that from the African perspective, the Supreme Being is ubiquitous, invisible and invincible. He is also immaterial and non-spatial.

There are also impersonal, mystical powers which are variously known as manna, life force, vital force or dynamism. The manifestation and use of the power are related to the practices of ritual 
International Journal of Arts and Humanities

ISSN: 2581-3102

Volume: 04, Issue: 02 "February 2020"

specialists who use natural objects such as plants and animals for medicine, charms, amulets and magic. They can be employed for both benevolent and malevolent purposes.

The belief in spirit beings is an integral part of ATR. This is because African traditional concepts of reality and destiny are deeply rooted in the spirit world. In fact, the activities of spirit beings govern all social and spiritual phenomena. Thus, the belief in mystical powers and spirit beings and the human quest to control or influence them have produced a variety of specialists. They include medicine men and women, rainmakers, diviners, seers, sorcerers, witches, mediums and magicians (Turaki, African Traditional). Finally, ancestral veneration and divination are cardinal parts of ATR.

\section{THEORETICAL FRAMEWORK}

This paper is girded by The Theories of Religion. This will enable one to present a systematic way of understanding the vitality of African Traditional Religion vis-à-vis Christianity. As a set of inter- related concepts, definitions and propositions, these theories can convincingly explain why Christianity has not succeeded in supplanting the African Traditional Religion (ATR). It will also show why on the other hand the ATR was exported to, and gathered force in continents outside Africa.

Theories of religion can be classified into two: the Substantive and the Functional. The substantive or essentialist theory is concerned with what religion is. It focuses on the contents of religions and what meaning these contents have for the practitioners. The theory holds that people have faith because beliefs make sense to them. This view is subscribed to by scholars like G. J Frazer, E. B Tylor, etc.

On the other hand, the functional theory deals with what religion does. Its concern is the social and psychological functions that religion performs for persons or groups. This theory focuses on the subconscious motives for people having belief, some of which are even irrational. It also deals with the relationship between religion and other social institutions. The guiding notion is that religion shaped the values that ground the major institutions of society just as many practical circumstances in society condition its religious life (Lidz 2010). The proponents include Karl Marx, Sigmund Freud, Emile Durkheim, etc.

Marx and Engels believe in the character of misapprehension that religion has. Thus, to them it is the opiate of the masses and produces false consciousness. By this they mean that the happiness and comfort that religion is capable of providing is temporary and illusive. Theirs is the extreme position that religion is not a necessary part of human culture and that it originates from and aids persistent alienation. 
International Journal of Arts and Humanities

ISSN: 2581-3102

Volume: 04, Issue: 02 "February 2020"

Edward Burnett Tylor defined religion as the belief in supernatural beings while this belief originated as explanations to phenomena such as life and death, afterlife, etc. J.G. Frazer holds that religion is the faith that the natural world is ruled by one or more deities with personal characteristics. For Durkheim (1912), the defining characteristic of religion is the concept of the sacred and not faith in the supernatural. He believes that one of the functions of religion is group cohesion. According to him, by participating in group meetings and rituals, people generated a special kind of energy which he referred to as 'shared effervescence'. This he defined as an emotionally heightened sense of communal identity. Group members lose their individuality. Communities were defined by what they took to be sacred. Going further, Durkheim stated that by inspiring people to believe in the same shared symbols, values and taboos and to act in similar ways on similar timeframes, religion proves to be the underlying ground for society.

A second function of religion identified by Durkheim is to provide social control. Enforcing religion-based morals and norms help to maintain conformity and control in society. Thirdly, religion offers meaning and purpose by answering many existential questions. Durkheim therefore sees religion as an expression of man's collective consciousness which then creates a reality of its own. Then, he concludes that since it is an expression of society itself, there is no society without religion.

Geerz (1973) also contributed to the theory of religion. According to him, religion is a system of symbols which acts to establish powerful, pervasive and long-lasting moods and motivations in men by formulating conceptions of a general order of existence and clothing them with such an aura of factuality that the moods and motivations seem uniquely realistic. On culture, Geerz holds that religion is what transmits the meanings of symbols down through generations thus allowing culture to function. So, a culture where nobody agrees on symbols or their meanings is not really a culture. And symbols ultimately spring from religious sources.

In agreement, Max Weber declares that religion profoundly influences culture by shaping what people believe about the world. He examines how religious ideas and groups interacted with other aspects of social life including the economic. In this way, he attempts to get at religion's subjective meaning to the individual. Weber also holds that a religious group or individual is influenced by all kinds of things, but that if they claim to be acting in the name of religion, one should attempt to understand their perspective on religious ground first. For him, religion is best understood as a response to the human need for theodicy and soteriology. Theodicy is concerned with the question of how the extraordinary power of a divine god may be reconciled with the imperfection of the world he has created and rules over. Or why the undeserved get suffering and fortune in the world. On the other hand, soteriological answers provide opportunities of salvation, relief from suffering as well as reassuring meanings. The pursuit of salvation then 
International Journal of Arts and Humanities

ISSN: 2581-3102

Volume: 04, Issue: 02 "February 2020"

becomes a part of human motivation. He gives the example of Christianity which he claims sought to conquer and change the world rather than withdraw from its imperfections.

Finally, Reisebrodt (2010) sought to justify a general concept of religion and explain the vitality of actual religions across diverse historical periods and cultural settings. He defined religion with interventionist practices as the center of analysis. For him, interventionist activities refer to any type of practice aimed at establishing contact with superhuman powers with the object of averting or mitigating misfortune and securing salvation in areas of existence. He identifies the levels of existence as individual, social and natural environment. And as far as he was concerned, the main issue is: how is religion relevant in these three areas of acute human vulnerability?

\section{SANTERIA: THE EXPORT OF AFRICAN TRADITIONAL RELIGION (ATR)}

Perhaps, there is no better proof of the vitality of the African Traditional Religion (ATR) than the fact that it was exported outside the shores of its origin and it is still a formidable part of the belief system in some parts of the world. Between the $15^{\text {th }}$ and $19^{\text {th }}$ centuries, the Trans Atlantic Slave Trade took place. African slaves were shipped to the New World and put to cruel labor on the plantations. The slave owners sought to convert them to Christianity but the traditional religion of the Africans would not give way. Instead, the resilient ATR added Christian forms and syncretism is known as Santeria.

Santeria in Spanish means the worship of saints. The religion is also known as Regla de Ocha, La Regla de Ifa or Lukumi. Originally, it was derisively used to describe what the Spanish masters thought was the African slaves' infantile preference of the worship of Catholic saints to that of the Almighty God (Wiki). Actually, it is an Afro-Caribbean religion that developed in the Spanish Empire among West African descendants. It was based on Yoruba beliefs and traditions mingled with some Roman Catholic elements (BBC, 2014). The enslaved Yoruba people carried with them their religious customs including a trance and divination system for communicating with their ancestors and deities, animal sacrifice, and sacred drumming and dancing.

The Spanish plantation owners in Cuba made efforts to convert their slaves to Catholic Christianity. Even as the slaves accepted much of the new faith, they did not find sufficient spiritual fulfillment in it. So, while outwardly professing Christianity, they continued to practice their traditional rituals which they found to be more useful and effective. The ATR filled in them the spiritual space in their lives that were torn from the original cultural foundation (BBC, 2014). The enslaved Africans found themselves in a period of perseverance. In a hostile cultural environment, the African slaves had the need to preserve their traditions and belief system. Colonial laws criminalized their religion while the harsh plantation conditions necessitated strategies for individual survival. Therefore, Santeria provided sustaining hope. 
International Journal of Arts and Humanities

ISSN: 2581-3102

Volume: 04, Issue: 02 "February 2020"

In Santeria, the Supreme God is recognized as Olodumare. However, human interaction with the divine focuses on the many Orishas (saints, spirits). An individual believer generally develops a special relationship with a particular Orisha which during worship may possess the body of the believer. Rituals and ceremonies of this religion took place in house-temples (house of saints) known as Ile and were spearheaded by Santeros (priests) and Santerias (priestesses) who are also called Olorisha. In Santeria rituals, there are musical ceremonies and prayers dedicated to the Orishas. Through heavy drumming and dancing, messages of worshippers reach the Orishas and elicit their responses.

An important component of Santeria is a traditional healing practice based on ethno-medicine. This practice has a holistic approach acknowledging the connection between the heart, mind and body. There were Orishas that were patrons of the healing process. For instances, Osain was the master herbalist that commanded the healing secrets of plant life. He is syncretised with the Catholic Saints Joseph, Benito and Jerome. Babalu Aye the Orisha of contagious and epidemic diseases is revered by victims and survivors of smallpox, leprosy and skin diseases. He has also become the guardian of those with HIV/AIDS. He is syncretised with Saint Lazarus. Finally, Inle is the patron of physicians and recognized as a healer who favors scientific methods. He is the protector of homosexuals and feminosexuals (Wiki) To the Afro-Cubans, the nature of the syncretism was such that both Christianity and ATR continued to run parallel in their minds and they did not see any contradictions between them.

For centuries, Santeria was practiced as a secret religion to avoid both religious persecution and negative social stigma. However, with time, it gained prominence and spread from Cuba to the USA, Canada, Europe and South America. Its spread beyond the Spanish speaking areas of the Caribbean was catalyzed by the Cuban Revolution of 1959. Since then, Santeria has gained much influence on the American culture. The first Santeria Church to be officially incorporated in the USA in 1974 was the Church of the Lukumi Babalu Aye. In 1983, the city of Hialeah in Florida banned animal sacrifice. This Church went to court. In its ruling, the US Supreme Court ruled that the ban was an unconstitutional infringement on freedom of religion (Timothy 2007). This gave further impetus to Santeria.

Since the 1980s, a new wave of conversion to Santeria had been noticeable in the US, especially among African Americans. African healing practices have been introduced while Babalawos (diviners) are known to practice in major American urban centers such as Atlanta, Miami and New York City. The US Army and Federal Bureau of Prisons have incorporated Orisha ministries into their Chaplaincies. The Orishas are believed to provide devotees with protection, wisdom and success. Thus, musicians, painters, sculptors and writers have found in Santeria sources of African artistry and pride (Encyclopedia Britannica, 2010). 
International Journal of Arts and Humanities

ISSN: 2581-3102

Volume: 04, Issue: 02 "February 2020"

\section{THE STRENGTH OF AFRICAN TRADITIONAL RELIGION VIS-À-VIS CHRISTIANITY}

In spite of the vigorous evangelical efforts of Christian bodies, a significant and sustained syncretism between Christianity and the African Traditional Religion (ATR) continue to exist (Wikipedia). While many African adherents confess Christianity, they consciously or unconsciously tap into their past religious experience. This brings about hypocrisy and duplicity such that the Christian God may be worshipped on Sunday while other days are for the African gods. And in some cases, adherents profess Christianity openly while they have recourse to the African gods secretly.

A number of reasons have been adduced for this scenario. Njoku (2013) holds that Africans had an ambiguous experience. They were exposed to both their ATR and the mental world of the modern Western societies. She maintained that with Christianity, Africans were introduced to a new religion which did not always provide such quick intervention as the ATR does. And that the African considered it normal and appropriate to have many gods for a variety of human needs. This was corroborated by Nwokoro (2014) when he said that Africans find ATR swifter than Christianity in the face of life's challenges. Thus, the allegiance of some African Christians goes alloyed when crises strike. Nwadialor (2012) declares categorically that "the Church is unable to meet the spiritual needs" of the African converts. In the same vein, the 'Manual of the Laity' (2009) holds that in time of adversity, African Christians "innocently" take recourse to their traditional religion or its "home-brewed" Pentecostal equivalent where there is no clear-cut divide between divination, magic, miracles, vision and prophecy. This makes Christianity a fair weather choice of religion which serves mainly to provide prestige and social respectability.

The African who lives in a spirit-dense environment requires the functionality of religion to combat his existential challenges. He has to court the favor of the benevolent spirits and ward off the malevolent ones and his enemies who invoke them against him. Also, in the African's quest for meaning, he wants to find out what lies behind every incident in life such as catastrophes, natural disasters, diseases, death, barrenness, witchcraft attack and other misfortunes. Also, the African has an all-consuming concept of power. Since his needs cannot be met without power, a powerless religion is valueless to him. Also, as faith is a religious phenomenon that is believed to work for the ardent believer, African Christianity is thrust into deep crisis when adherents' faith in Christianity refuses to be favorably disposed towards satisfying these needs and expectations (Nwokoro 2014). When he faces such disappointment, his faith in ATR is reinforced.

It is also worthy of note that religious beliefs, feelings, practices and behaviors have roots and bases. Thus, when the belief in the potency of mystical and mysterious powers and forces are condemned as demonic, the African man needs to know why. To him, they work and he sees and 
International Journal of Arts and Humanities

ISSN: 2581-3102

Volume: 04, Issue: 02 "February 2020"

experiences their power, potency and efficacy. A mere reference to a Bible verse or such abstracts are not enough to dissuade and convince him to believe otherwise (Turaki, African Traditional ).

Christian ethics have largely failed to supplant the African traditional worldview and pedagogy. This can be traced to the faulty foundation of early missionary enterprise in Africa. From the onset, Christian proselytizers had underrated the force of the traditional religion as well as the dynamics of the African society. They had ignored, misconceived or misconstrued the importance of some African customs and institutions in the stability of society. These were easily written off as products of superstition. It was also erroneously believed that the less African a convert was, the more Christian he/she became. Unfortunately, such ideas were inhibitive to the acceptance of the new religion by Africans.

The missionaries failed to realize that among Africans, religion was the cement of the society, the guarantor of moral principles and the basis of secular authority. Thus, the Christian perception of religion as concerning mainly the affair between an individual's soul and his God, contrasts with the African communal conception of religion. Thus, Nwadialor (2012) insists that the existence of an individual cannot be conceived outside the framework of his integration in society; while Acquah (2011) holds that to be born into an African society is to be born into a culture that is intensely and pervasively religious, and that means and requires participation in the religious beliefs and rituals of the community. The cultural context is quite crucial. Christianity will continue to have limited success in Africa since its aim is to evangelize an individual and not his culture. This is because Africans do not live in a cultural vacuum. Their cultural environment conditions their mentality, thought, behavior and life. This is what informed Nwadialor (2012)'s suggestion of an African way of being a Christian and a Christian way of being an African.

Christianity has been influenced by Western Dualism which creates serious theological problems for the traditional African who has organic or holistic views of life. Unlike the Christian conception, the African does not draw a distinction between the physical, material or spiritual. He does not differentiate between the sacred and profane, the secular and the religious; between his profession and his communal responsibilities. They all knit together in a whole (Acquah 2011; Turaki; Mandela, 1994). Tennent (1994) adds that in the Christian West, there is no open frontier approach as obtained in Africa between the visible and invisible where spirits, deities and God all interact in a dynamic way.

\section{CONCLUSION}


International Journal of Arts and Humanities

ISSN: 2581-3102

Volume: 04, Issue: 02 "February 2020"

Syncretism between Christianity and ATR has come to stay. Most of the African Christian converts could not just break away from their indigenous religious and cultural element. Their Christian convictions and experiences were still underpinned by the indigenous values and religious thought that have been the basis of their nurturing and socialization. Moreover, Christianity lacked credible spiritual response to some of their challenges. The consequent frustration compelled the converts to resort to ATR (Acquah, 2011). In view of this situation, there is a need for a realistic adjustment.

Although some Christian groups have acknowledged this situation and made some allowance, Christianity is still largely regarded as foreign in character and alien to the life and institutions of Africans. Through the policy of Inculturation, the Catholic Church especially has tried to come to terms with the challenge of the cultural diversity confronting evangelization. This is the adaptation of the way Church teachings are presented to non-Christian cultures and in turn the influence of those cultures on the evolution of these teachings. There is also the Contextual Theology which apart from all that is included in Inculturation, also takes cognizance of the realities of contemporary, secularity, technology as well as the struggles for human justice. However, more holistic strategies are required.

All said and done, it is crucial for Christian evangelization to make the gospel message suit the African religious and cultural environment. For Christianity and ATR to co-exist, they must enter into a relationship of give and take by means of interaction and adaptation; a realistic relationship that recognizes and respects Africans' spiritual, moral and social peculiarities. This should not be difficult bearing in mind that it was on such basis that Christianity itself came to be. According to Canfield, the roots of Christianity are interlaced with some of the most ancient pagan traditions and elements mainly because the Church gained power through conversion. In order to win converts in Europe and other parts of the world from their pagan beliefs, the Church had to accept or adopt some of these beliefs into the Christian religion. The same was done for some pagan festivities and their periods. More of such adaptation should be done with respect to the African Traditional Religion.

\section{REFERENCES}

1. Acquah, Francis. 2011. The Impact of African Traditional Religious Beliefs and Cultural Values on ChristianMuslim Relations in Ghana from 1920 through the Present: A Case Study of Nkusukum-Ekumfi-Enyan area of the Central Region. PhD Thesis Submitted to the University of Exeter. 
International Journal of Arts and Humanities

ISSN: 2581-3102

Volume: 04, Issue: 02 "February 2020"

2. Adamo, D.T. 2011, 'Christianity and the African Traditional Religion(s): The Postcolonial Round of Engagement'. Verbum et Ecclesia, vol. 32. no. 1. Art. \#285. https://doi.org/10.4102/ve.v32i1.285

3. Boaheng, P. 2012. "God and the Traditional African Experience: Shattering the Stereotypes". Thinking About Religion.

4. Canfield, N. Christianity's Pagan Roots: Traditions, Practices and Holidays. Owlsetion

5. Catholic Laity Council of Nigeria: Manual of the Laity Week, 2000

6. Chicago Divinity School, 2011. "Comparing Religions: On Theory and Method". A Conference in Honour of Martin Reisebrodt. http://divinity.uchicago.edu $>$ comparingreligions.theoryandmethods.conference.honor.ma rtin.reisebrodt.professor.sociology

7. Durkheim, E. 1912. The Elementary Forms of the Religious Life.

8. Frazer, J.G. Theories of Religion. https://en.wikipedia.org/wiki/James George Frazer

9. Geerz, C. 1973. The Interpretation of Cultures: Selected Essays. Basic Books. New York.

10. Hassan, T.L. Attitudes of Christian Missionaries Towards African Traditional Religious Beliefs in East Africa During the Colonial Rule. https://academicjournals.org/journal/AJHC/article-full-text/5D944D155369

11. Hornby, A. S. 2010. Oxford Advanced Learner's English-Chinese Dictionary (8th Edition). New York: Oxford University Press.

12. Lidz, V. 2010. The Functional Theory of Religion. https://en.wikipedia.org/wiki/Sociology of religion

13. Lippy, C.H. \& Williams, P.W. (eds). 1998. Encyclopedia of the American Religious Experience Studies of Traditions and Movements. BBC.

14. Microsoft ${ }^{\circledR}$ Encarta ${ }^{\circledR}$ 2009. $\odot 1993-2008$ Microsoft Corporation.

15. Newman, J.L. 2008. "Africa". Microsoft ${ }^{\circledR E n c a r t a}{ }^{\circledR}$ 2009. $@ 1993-2008$ Microsoft Corporation.

16. Njoku, M.G.C. 2013. The Psychology of Syncretic Practices Within the Church. Paper Presented at the 3rd Synod of the Catholic Diocese of Enugu. 
International Journal of Arts and Humanities

ISSN: 2581-3102

Volume: 04, Issue: 02 "February 2020"

17. Nwadialor, K.L. 2012. Christianity and Ndoshimili Culture, 1841 - 1940: A Historical Perspective. International Journal of Theology and Reformed Tradition. Vol. 4. pp. 90102

18. Nwokoro, S.O. 2014. The Influence of Traditional Religion on African Christianity. Lecture Delivered at Nigerian Fellowship of Evangelical Students (NIFES). Conference centre. Abuja

19. Sourou, J.B. 2014. African Traditional Religion and the Catholic Church in the Light of the Synods for African: 1994 and 2009, African Human Rights Law Journal. Vol. 14. no. 1

20. Tennent, T. 1994. Introduction to African Religion. https://www.biblicaltraining.org/library/introduction-african-traditionalreligion/essentials-african-traditional-religions/timothy-tennent

21. Timothy, M. 2007. "Santeria". Microsoft ${ }^{\circledR E n c a r t a}{ }^{\circledR}$ 2009. $@ 1993-2008$ Microsoft Corporation.

22. Turaki, Y. African Traditional Religious System as Basis of Understanding Christian Spiritual Warfare. https://www.lausanne.org/content/west-african-case-study

23. Tylor, E.B. Theories About Religion. https://en.wikipedia.org/wiki/Theories_about_religions

24. Weber, M. Sociology of Religions. https://en.wikipedia.org/wiki/Sociology of religion

25. Wikipedia, 2019. Marxism and Religion. https://en.wikipedia.org/wiki/Marxism and religion

26. Wikipedia. "Inculturation" https://en.wikipedia.org/wiki/Inculturation

27. Wikipedia. "Santeria" https://en.wikipedia.org/wiki/Santer\%C3\%ADa 